\title{
Thresholds for morphological changes on an exposed sandy beach as a function of wave height
}

\author{
L. P. Almeida,* Ó. Ferreira and A. Pacheco \\ CIMA, University Algarve, Faro, Portugal
}

Received 4 March 2010; Revised 30 June 2010; Accepted 7 July 2010

*Correspondence to: L. P. Almeida, CIMA, University Algarve, Campus de Gambelas, 8005 Faro, Portugal. E-mail: Ipmelo@ualg.pt

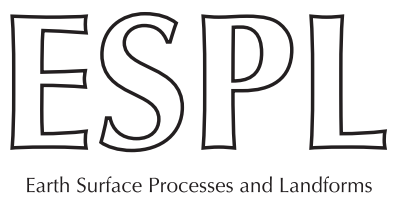

ABSTRACT: A sandy beach in the south of Portugal (Faro beach, Ria Formosa) was surveyed from the dune crest seaward to $15 \mathrm{~m}$ depth 20 times over a period of 26 months. Wave time-series between surveys were analysed to obtain relationships between wave height and vertical profile variations and to define wave thresholds for important morphological changes. Results show that the active zone of the profile lies between $5 \mathrm{~m}$ above and 10.4 $\mathrm{m}$ below mean sea level, and that there are clear cross-shore differences in the vertical variability of the profile. Based on the pattern of vertical variability, the profile was divided into four cross-shore sectors: A (berm), 20-80 m from the profile origin; B (sub-tidal terrace), 80-170 m; C (long-shore bar), 170-360 m; and D, 360-700 m. The relationship between the modulus of the maximum vertical change in each sector and the 99th percentile of significant wave height between surveys was always significant. Calculated thresholds for significant wave height generating important morphological changes were $2.3 \mathrm{~m}$ in sector A, $3.2 \mathrm{~m}$ in sectors B and C, and $4 \cdot 1 \mathrm{~m}$ in sector D. Copyright (C) 2010 John Wiley \& Sons, Ltd.

KEYWORDS: morphological thresholds; beach profile; cross-shore sectors; vertical variability; wave conditions

\section{Introduction}

Studies of sediment dynamics in the coastal zone show that storm waves cause sediment to move offshore, while fairweather waves and swell return the sediment shoreward (e.g. Komar, 1976; Wright and Short, 1984; Lee et al., 1998; van Rijn, 2009). The most rapid and dramatic changes in beach morphology occur during storms, and many investigations have studied the impact of extreme single storms (e.g. Birkemeier, 1979; Dolan and Hayden, 1981; Balsillie, 1986, 1997; Dolan and Davies, 1994; Ferreira et al., 1995; Morton et al. 1995; Fenster et al., 2001; Honeycutt et al., 2001; Zhang et al. 2001; Morton, 2002; Backstrom et al., 2008). More recently, interest in the impact of storm groups has increased (e.g. Steetzel, 1993; Lee et al., 1998; Birkemeier et al., 1999; Cox and Pirrello, 2001; Lozano et al., 2004; Ferreira, 2005, 2006; Callaghan et al., 2009). Study of sedimentary exchanges between morphologic features of the beach profile, and their relationship to wave conditions, encompasses many different processes acting over wide spatial and temporal scales (De Vriend, 1991; Larson and Kraus, 1995; Reeve et al., 2007). As a consequence, uncertainty remains in the prediction of morphodynamic changes in beach systems. Thresholds mark major changes in system response for a variable reaching a critical level (Woodroffe, 2002). This definition can be applied to different processes occurring in beach systems, such as wave conditions (the variable) that trigger relevant morphological changes (the system response). Since wave height is the single most important determinant of beach type and changes in beach conditions (Short, 1999), the objectives of this paper are to determine the relationship between wave height and beach profile vertical variability, and to establish the wave height threshold responsible for important morphological changes across the beach profile. In order to accomplish these objectives, a new methodology is developed that should find application on other beaches with morphodynamic behaviour similar to that of the case-study examined here.

\section{Study Area}

The study area, the Ancão Peninsula, is situated in the westernmost part of the Ria Formosa barrier island system in the Algarve region of southern Portugal (Figure 1). The area is an open sandy shore without underlying geological control. From the peninsula's eastern attachment to the mainland, the dune ridge decreases in height from c. $9 \mathrm{~m}$ to c. $6 \mathrm{~m}$ above mean sea level (m.s.l.) (Ferreira, 2006). In the central area of the Peninsula (known as 'Praia de Faro'), the dune ridge has been almost completely destroyed by human settlement. The eastern part of the Ancão Peninsula has a low population density, located mainly along the backbarrier. The eastern part of the peninsula possesses less sedimentary stock at the shoreface, giving it an erosional tendency (Martins et al., 1997; Ferreira et al., 1997; Ferreira, 2006). In contrast, the eastern part of Praia de Faro is characterized by a large vegetated area on the higher part of 


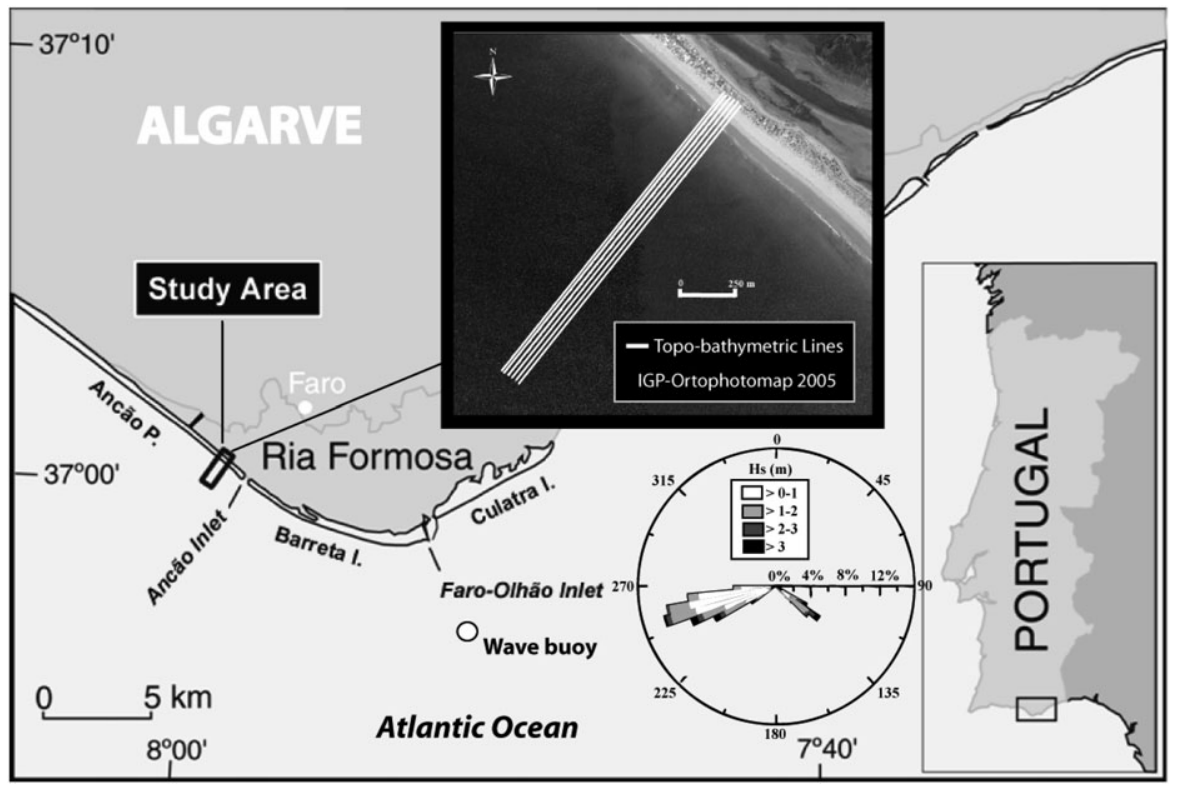

Figure 1. Study area (adapted from Vila-Concejo et al., 2006) showing the topo-bathymetry profile locations (over a 2005 ortophotomap), wave buoy location and a wave rose obtained from the wave dataset used in this work.

the upper beach, and has an accretional tendency (Ferreira, 2006). Net long-shore and littoral drift in this area is typically from west to east, and various estimates of the rate of movement are found in the literature: $10 \quad 000-20 \quad 000 \mathrm{~m}^{3} / \mathrm{yr}$ (Andrade, 1990); $20000-40000 \mathrm{~m}^{3} / \mathrm{yr}$ (Bettencourt, 1994); 40 $000 \mathrm{~m}^{3} / \mathrm{yr}$ (Correia et al., 1997) and $34800 \mathrm{~m}^{3} / \mathrm{yr}$ (DGPNTM, 1998). Beach morphological changes are mainly due to crossshore processes that produce major exchanges between the bar and berm (Martins et al., 1997). Tides in the area are semi-diurnal, with average ranges of $2.8 \mathrm{~m}$ for spring-tides and $1.3 \mathrm{~m}$ for neap tides, attaining maximum ranges of $3.5 \mathrm{~m}$. Wave climate in the area is moderate to high (Ciavola et al., 1997), with an average annual significant offshore wave height (Hs) of $0.92 \mathrm{~m}$ and an average peak period of 8.2 seconds (Costa et al., 2001). The cuspate shape of the Ria Formosa system produces two areas differentiated in terms of their exposure to wave action. The predominant wave direction is from the west-southwest (W-SW), accounting for $71 \%$ of observations, while waves approaching from the eastsoutheast (E-SE) account for 23\% of observations (Costa et al., 2001). In this area, storms have been defined as events where $\mathrm{Hs}$ is greater than $3 \mathrm{~m}$ (Pessanha and Pires, 1981; Pires, 1998). The dominant storms arrive from the W-SW, although the E-SE ('Levante') storms can also be important.

\section{Methods}

The methodology comprises a five-step sequence, consisting of: (1) the definition of the profile active zone; (2) the establishment of cross-shore sectors; (3) the determination of volumetric changes; (4) the determination of vertical variability; and (5) the definition of thresholds of morphological change using the relationship between wave height and profile vertical variability.

\section{Overall profile active zone}

Between July 2001 and September 2003, a series of 20 shorenormal surveys was obtained and subsequently analysed. The survey period covered five seasons (Table I), including three summers (maritime summer defined as April-September) and two winters (maritime winter, October-March). The surveys
Table I. Surveys and number of days between consecutive surveys

\begin{tabular}{lcc}
\hline Survey date $(\mathrm{dd} / \mathrm{mm} / \mathrm{yy})$ & Survey & Interval between surveys (days) \\
\hline $23 / 07 / 01$ & 1 & - \\
$23 / 08 / 01$ & 2 & 32 \\
$20 / 09 / 01$ & 3 & 28 \\
$25 / 09 / 01$ & 4 & 5 \\
$26 / 11 / 01$ & 5 & 62 \\
$12 / 02 / 02$ & 6 & 78 \\
$20 / 02 / 02$ & 7 & 8 \\
$04 / 03 / 02$ & 8 & 12 \\
$23 / 05 / 02$ & 9 & 80 \\
$19 / 06 / 02$ & 10 & 27 \\
$27 / 06 / 02$ & 11 & 8 \\
$01 / 07 / 02$ & 12 & 4 \\
$09 / 07 / 02$ & 13 & 8 \\
$17 / 07 / 02$ & 14 & 8 \\
$25 / 07 / 02$ & 15 & 8 \\
$03 / 09 / 02$ & 16 & 40 \\
$29 / 10 / 02$ & 17 & 56 \\
$25 / 01 / 03$ & 18 & 88 \\
$13 / 05 / 03$ & 19 & 119 \\
$25 / 09 / 03$ & 20 & 135
\end{tabular}

involved measurements along six beach profiles spaced $20 \mathrm{~m}$ apart (from west to east, profiles 1-6) and extending from the dune crest to depths of about $15 \mathrm{~m}$ below m.s.l. (Figure 1). Beach topography was measured with a total station with auto-tracking. Bathymetric profiles were obtained using an echo-sounder combined with real time kinematic differential global positioning system (RTK-DGPS) measuring at $1 \mathrm{~Hz}$. Navigation along each beach profile, as well as data assimilation between the ecosounder and the RTK-DGPS, was made using HYPACK $\mathbb{R}$ 4.3a Gold software, allowing recorded depths to be immediately corrected for water level variations (i.e. tides and waves). Errors related to equipment operation (Sá-Pires et al. 2002) comprise a vertical error of $\sim 10 \mathrm{~cm}$ for the topographic survey using the total station, and an error of up to $11 \mathrm{~cm}$ for the combined RTK-DGPS plus echo-sounder system used for bathymetry. Since those errors can be either negative or positive, an overall maximum accuracy of about $20 \mathrm{~cm}$ can be expected. The active zone of the overall ('mean') profile was defined by graphically overlaying all elevation data standard deviations $(\sigma)$ calculated between each pair of con- 
secutive surveys for the six profiles measured. The upper and lower limits of the beach (i.e. the closure depth) were defined when $\sigma \leq 20 \mathrm{~cm}$, enclosing the range of errors derived from the instrumentation used. The closure depth was also determined using Hallermeier (1981) and Birkemeier's (1985) empirical methods for comparison.

\section{Cross-shore sectors}

After delimiting the overall profile active zone, a detailed analysis of the six profiles' vertical variations and standard deviations was performed, aiming to divide the overall profile into sectors and thereby identify the main active zones and their role in establishing a dynamic equilibrium profile (e.g. sedimentary exchanges occurring between sectors). Division of the overall profile into sectors was based on the similarity of the patterns derived from the standard deviation computation for all surveys for each of the six profiles. Sectors were defined by identifying the parts of the overall profile with a smaller standard deviation (nodes of smaller morphological changes) that separated the parts with a larger standard deviation (most important morphological changes). Parts of the overall profile with a larger standard deviation should correspond to beach features (e.g. berm or bar position), while the parts with a smaller standard deviation should correspond to transitional parts of the profile. Winant et al. (1975) and Inman and Dolan
(1989) have made similar segmentations of beach profiles previously.

\section{Volumetric variation}

The accretion/erosion volume for each profile sector was computed using the trapezoidal integration method. The lower/ upper profile limits used for computations were defined using the 20 surveys for each profile. Volumes were also individually computed for each defined cross-shore sector. After obtaining the volume for each sector in each profile, correlations between sectors were determined in order to analyse intersector volumetric relationships. The statistical significance of each result was inferred in respect to the 0.01 and 0.05 levels, using the Pearson correlation coefficient.

\section{Profile vertical variability}

Maximum vertical variation (MVV) of the beach profile was determined for each sector by calculating the modulus of the maximum difference between two consecutive surveys, highlighting those survey intervals during which important vertical changes occurred. The threshold for important vertical variations was established for each sector, taking into account measurement error $(20 \mathrm{~cm})$ and the amplitude of variations for each defined beach sector.
Figure 2. Overlap of all standard deviation values computed for each pair of surveys defining the upper (A) and lower (B) limits of the active beach zone.
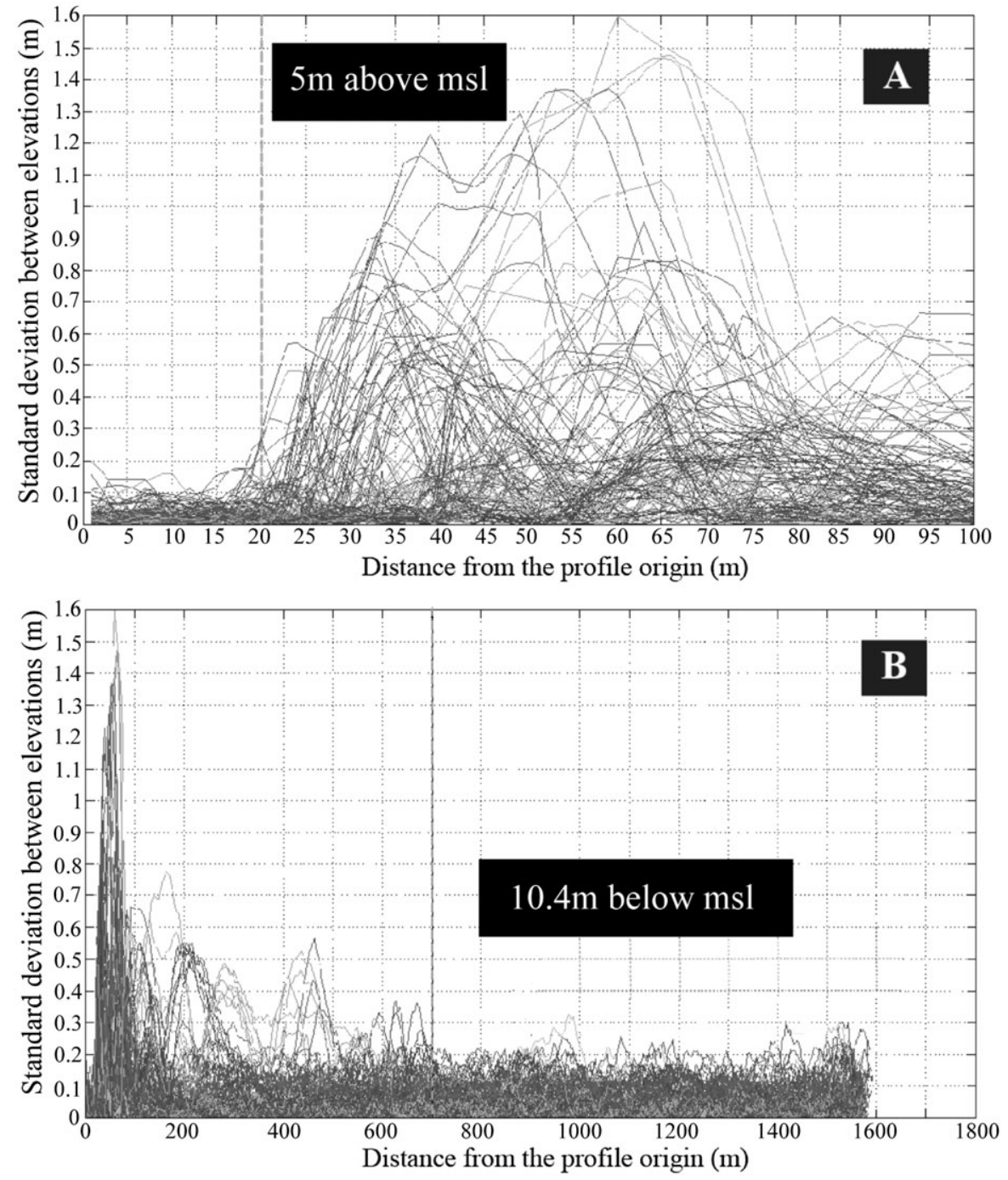


\section{Relationships between wave conditions and vertical variability}

Wave data from the directional wave-rider buoy offshore of Station Maria Cape (location 36 $54 \cdot 3^{\prime} \mathrm{N}, 07^{\circ} 53.9^{\prime} \mathrm{W}, 93 \mathrm{~m}$ depth; Figure 1) were provided by the Portuguese Hydrographical Institute $(\mathrm{IH})$. The buoy records significant wave height $(\mathrm{Hs})$, mean peak period $(\mathrm{Tp})$, and mean wave direction $(\theta)$ for 20 minutes every 3 hours, except during storm periods when data are recorded every half hour. The 99th percentile $\mathrm{Hs}$ value $\left(\mathrm{Hs}_{99}\right)$ was used to characterize each survey interval as it provides wave heights associated with high energy events such as storms. An average Hs for each interval would mask high energy events and would not be indicative of the most important morphological changes. The absolute maximum $\mathrm{Hs}$ of each interval could have been used, but a single high value (outlier) could occur without necessarily inducing important morphological changes. The use of the 99th percentile is a way of expressing the maximum energy conditions for each interval analysed, excluding potential outliers at the same time. Relationships between MVV and $\mathrm{H}_{99}$ were determined for the overall profile in each sector through the use of linear regression, yielding both a line of best fit and a significance level for the relationship. The calculated lines constrained the intercept through the origin assuming that there are no vertical variations when the Hs is zero. The resultant equations define the empirical relationships between offshore wave height and vertical variations in each sector, which enabled a significant wave height threshold for important morphological change to be calculated for each sector in the overall profile. In order to overcome the fact that survey intervals are irregular, the analysis focused on storm events capable of significant morphological changes. The assumption is that events of higher magnitude produce significant changes on the beach profile that are maintained through time. Differences between surveys grids were computed when $\mathrm{Hs}_{99}$ was higher than $3 \mathrm{~m}$.

\section{Results}

\section{Profile active zone}

The near-shore upper limit was determined to lie c. $20 \mathrm{~m}$ seaward of the profile origin (located on the dune crest), corresponding to a height of c. $5 \mathrm{~m}$ above m.s.l. (Figure 2A). The lower beach profile limit (or closure depth) was located at $C$. $10 \cdot 4 \mathrm{~m}$ depth (below m.s.I.), approximately $700 \mathrm{~m}$ offshore of the profile origin (Figure $2 \mathrm{~B}$ ). Variations outside the defined limits were considered negligible or inside the error interval. The closure depth is in accordance with the $10.5 \mathrm{~m}$ (below m.s.l.) obtained by Dolbeth et al. (2007) for the same study area. Empirical methods gave closure depths between $7 \mathrm{~m}$ (Birkemeier, 1985) and 9 m (Hallermeier, 1981).
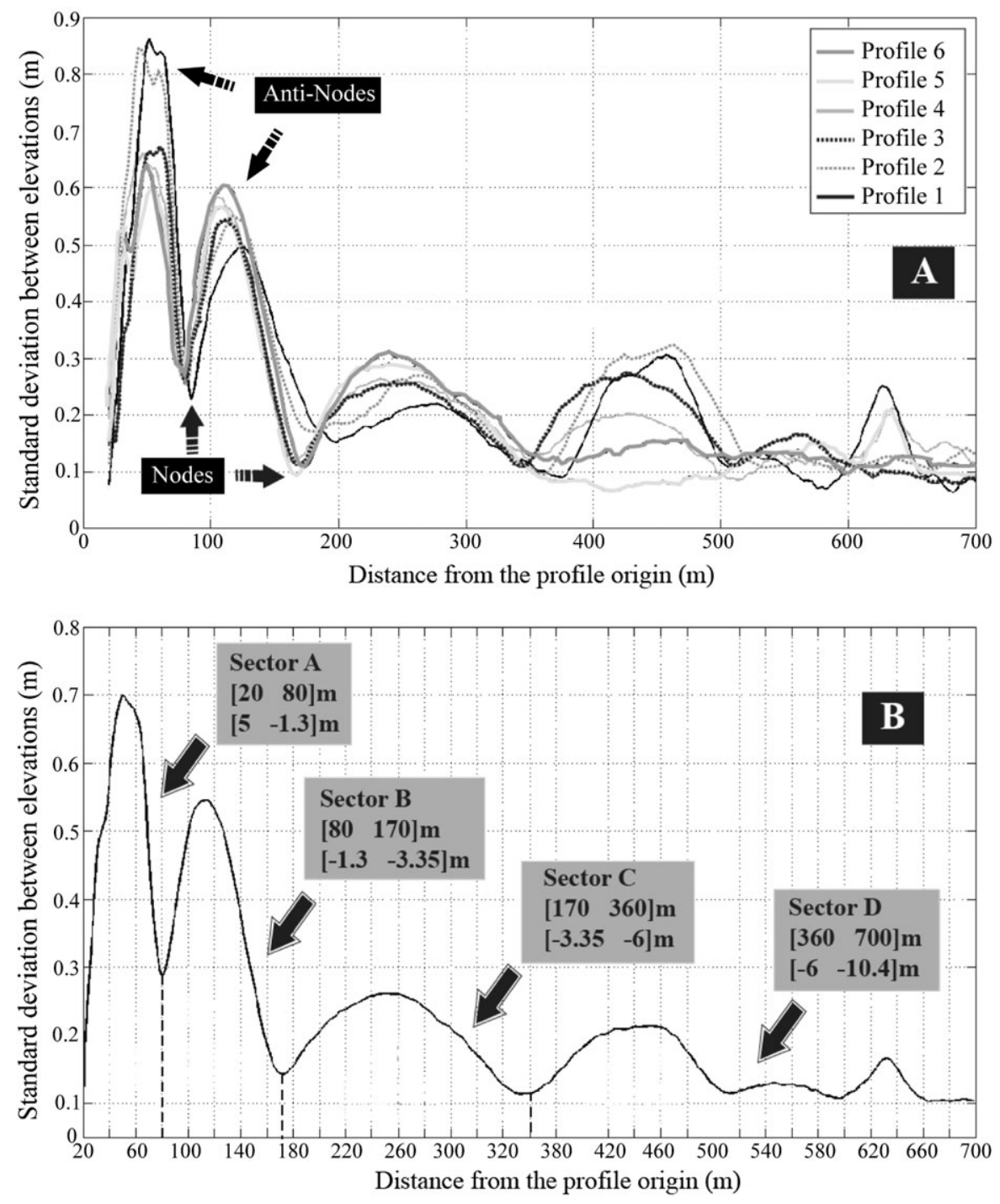

Figure 3. Overlap of average standard deviations for all surveys for each profile (A) and for the five profiles (B), and definition of four cross-shore sectors along the beach profile. 


\section{Cross-shore sectors}

Individual sectors are represented by sequences of high standard deviation values, related to higher vertical variability amplitudes (antinodes), separated by depressions with lower amplitudes (nodes) (Figure 3). On the basis of the antinodenode pattern, the beach profile was divided into four sectors (Figure 3B): sector A (from 20 to $80 \mathrm{~m}$ from the profile origin); sector B (between 80 and $170 \mathrm{~m}$ from the profile origin); sector C (from 170 to $360 \mathrm{~m}$ from the profile origin); and sector D (from 360 to $700 \mathrm{~m}$ from the profile origin). Sector A presents the highest variability, sector B presents intermediate values, and sectors $C$ and $D$ are characterized by the lowest variability (Figure 3B). Graphical comparison of the mean standard deviation for each profile shows a good agreement for the defined sectors, both in terms of amplitude and cross-shore location. The agreement is best for sectors A, $\mathrm{B}$ and $\mathrm{C}$, and worst for the deeper parts of the profile (sector D), where profile behaviour differs markedly (Figure 3A). The overlap of all surveys for beach profile 1 (Figure 4) allowed us to identify morphological features clearly related with sectors: (i) sector A is dominated by berm changes; (ii) sector B is predominantly a sub-tidal terrace (55\% of occurrences); and (iii) sector $\mathrm{C}$ includes the position of a long-shore bar (33\% of observations).

\section{Volumetric variation}

Profile volumetric variations for the period analysed, and for each sector, show clear and distinct behaviours (Figure 5). These trends are undoubtedly sector-dependent and can be positively or inversely related from sector to sector. For instance, at the beginning of the first winter, sectors A and C reveal erosion, while sector $\mathrm{B}$ shows volume recovery. The opposite occurs during the second winter. Inter-sector correlation coefficients for volumetric variation demonstrate different patterns between the profiles (Table II), as shown most dramatically through comparison of profiles 3 and 6. Despite the differences in correlation coefficients between profiles, the average of all coefficients reasonably represents the characteristics of overall relationships between sectors. Although
Figure 4. Overlap of all surveys for beach profile 1 , of the active profile zone, with shaded division of each cross-shore sector.

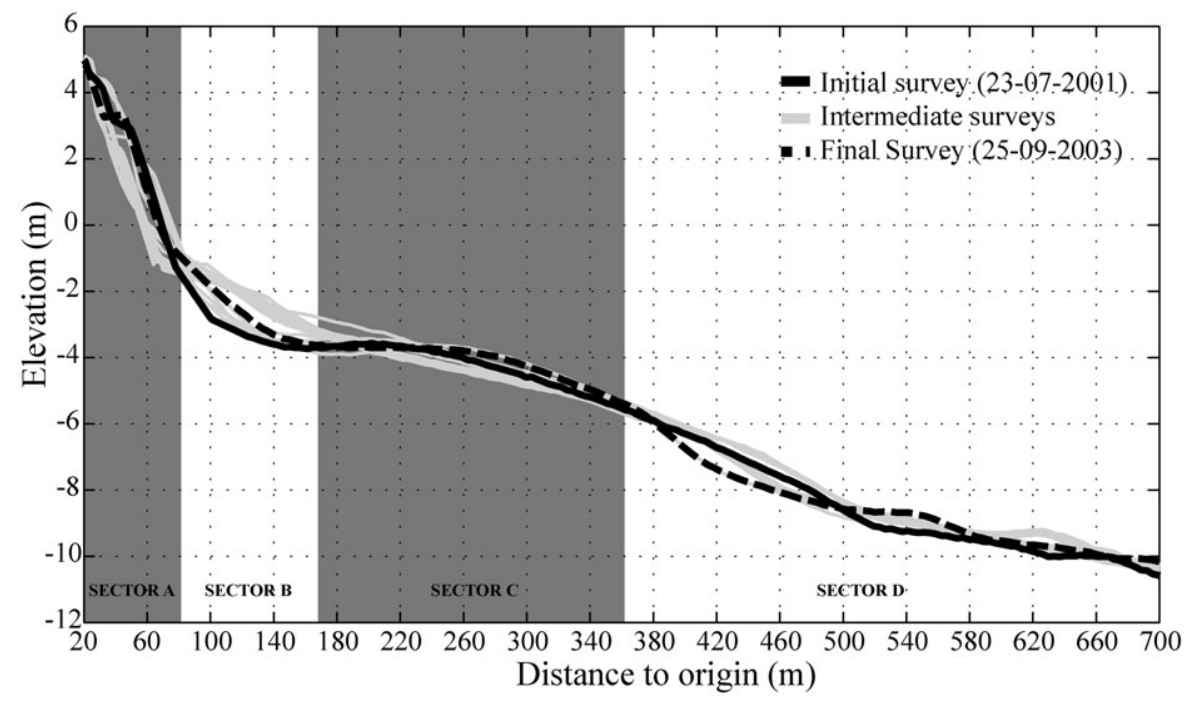

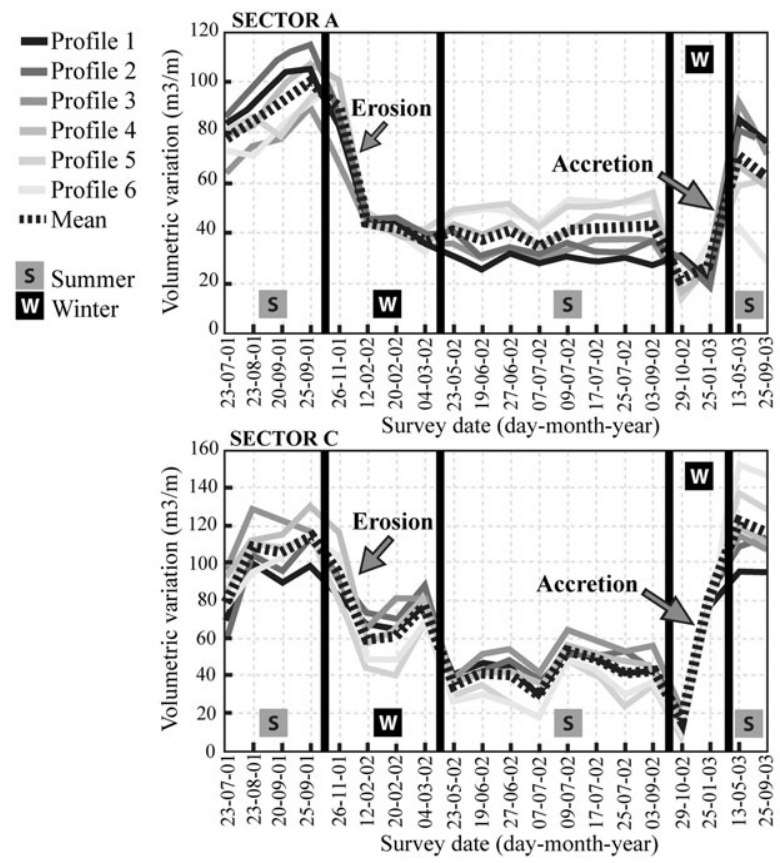

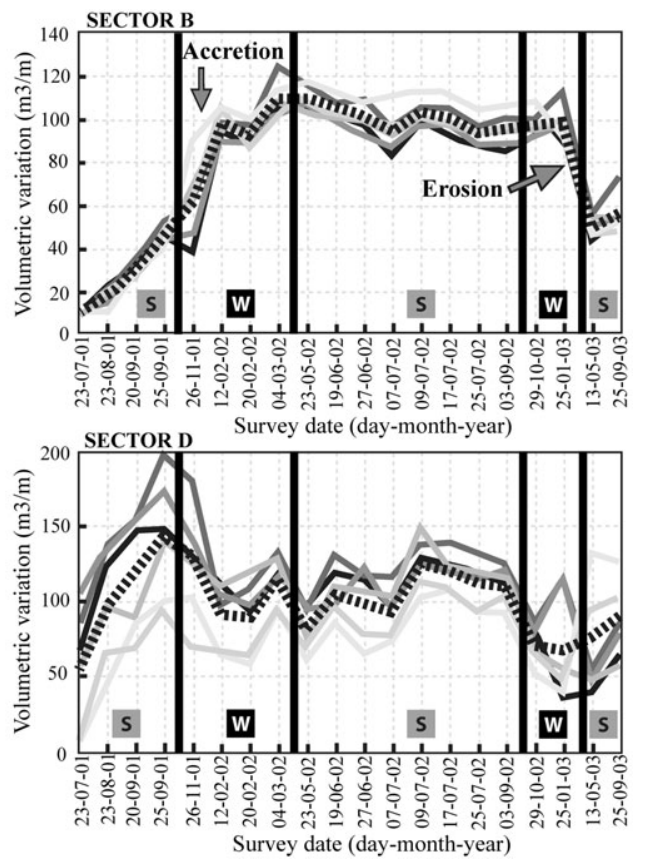

Figure 5. Volumetric variations in each sector of each profile during the monitored period. 
differences in correlation suggest some long-shore component, the correlation trends present the same behaviour through different sectors and profiles, providing evidence of beach cross-shore dominance. This observation was also made by Martins et al. (1997). The statistical significance of correlations between sectors show that $\mathrm{A} / \mathrm{B}$ (negative) and $\mathrm{A} / \mathrm{C}$ (positive) are significant at the 0.01 level, $\mathrm{B} / \mathrm{C}$ is negative at the 0.05 level, and C/D did not yield significant results at the levels tested.

\section{Vertical variability}

Sectors A and B presented generally higher values of MVV throughout the study period, while sectors $C$ and D presented high MVV values for only a small number of surveys (Figure 6). Determination of MVV (Figure 6), together with the

Table II. Correlation coefficient values of each linear fit established for each pair of sectors

\begin{tabular}{lllll}
\hline Profile & Sectors A/B & Sectors A/C & Sectors B/C & Sectors C/D \\
\hline 1 & $-0 \cdot 82^{*}$ & $+0 \cdot 64^{*}$ & $-0 \cdot 41^{* * *}$ & $+0 \cdot 0004^{* * *}$ \\
3 & $-0 \cdot 77^{*}$ & $+0 \cdot 54^{* *}$ & $-0 \cdot 27^{* * *}$ & $+0 \cdot 05^{* * *}$ \\
5 & $-0 \cdot 69^{*}$ & $+0 \cdot 75^{*}$ & $-0 \cdot 60^{*}$ & $+0 \cdot 10^{* * *}$ \\
7 & $-0 \cdot 63^{*}$ & $+0 \cdot 65^{*}$ & $-0 \cdot 56^{*}$ & $+0 \cdot 02^{* * *}$ \\
9 & $-0 \cdot 52^{* *}$ & $+0 \cdot 36^{* * *}$ & $-0 \cdot 62^{*}$ & $+0 \cdot 002^{* * *}$ \\
11 & $-0 \cdot 24^{* * *}$ & $+0 \cdot 11^{* * *}$ & $-0 \cdot 51^{* *}$ & $+0 \cdot 15^{* * *}$ \\
Mean & $-0 \cdot 74^{*}$ & $+0 \cdot 61^{*}$ & $-0.54^{* *}$ & $+0 \cdot 02^{* * *}$ \\
\hline
\end{tabular}

* Significant at the $p<0 \cdot 01$ level.

** Significant at the $p<0 \cdot 05$

*** Not significant.

Note: ' + ' positive relationship; ' - ' negative relationship.
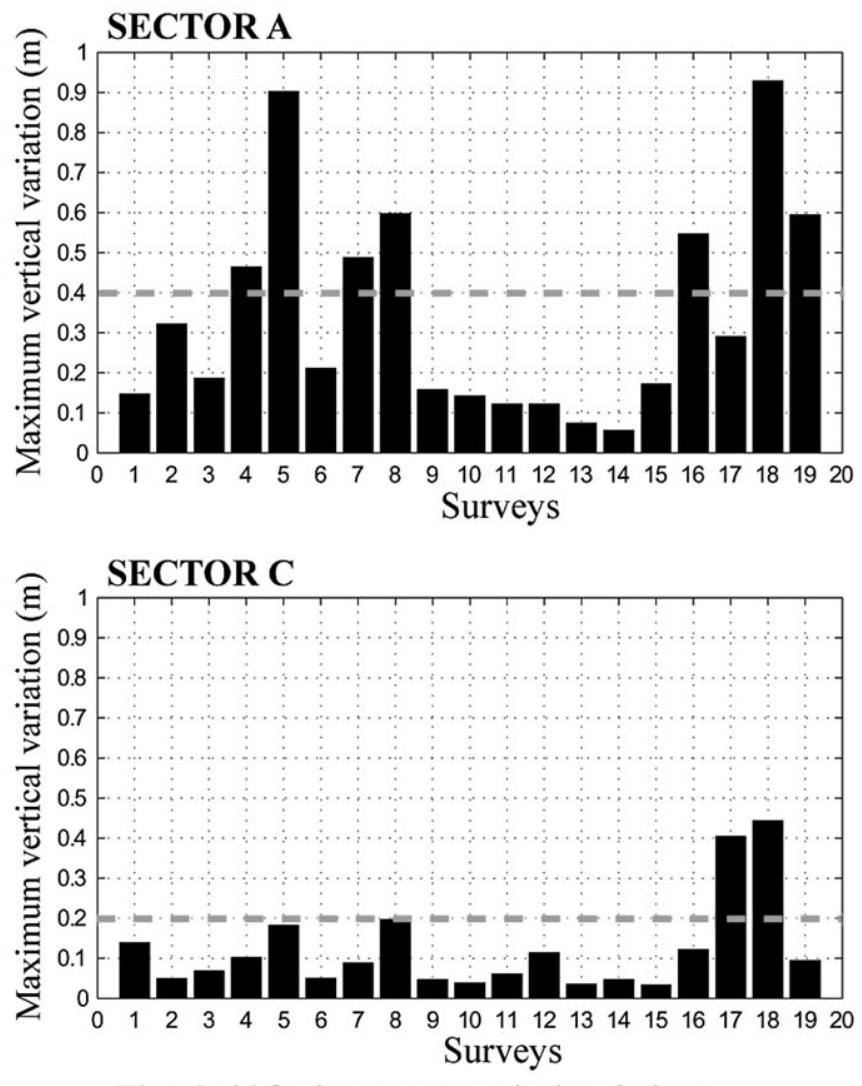

analysis of standard deviation (Figure 3), suggested a threshold for important vertical variations in each sector. For sectors $C$ and $D$, since these were the sectors with the lower average magnitude of vertical variations, the threshold was defined as any variation above the measurement error $(20 \mathrm{~cm})$. For sector B, which had an average magnitude of vertical variation 1.5 times higher than that observed in sectors $C$ and $D$, the vertical threshold was set at $30 \mathrm{~cm}$. For sector A, which presented an average magnitude of vertical variation in the order of 2-3 times higher than the variation observed in sectors $C$ and $D$, the threshold was defined as $40 \mathrm{~cm}$. These defined thresholds allowed us to distinguish the surveys in which important vertical variations occurred (surveys 5, 6, 8, 9, 17, 18, 19, and 20; Figure 6) in at least one of the sectors analysed.

\section{Wave conditions and vertical variability}

Six storm events occurred during the study period, with values of Hs ranging from 3 to $4.5 \mathrm{~m}$ (Figure 7). The relationship between MVV and $\mathrm{Hs}_{99}$ for each between-survey interval for each sector (Figure 8) was quantified using a least squares regression applied to each sector. The resulting empirical relationships between $\mathrm{MVV}$ and $\mathrm{Hs}_{99}$ for the different sectors are:

$$
\begin{aligned}
M_{\mathrm{VV}} & =0.1712 \cdot \mathrm{Hs}_{99} \\
\mathrm{MVV}_{\mathrm{B}} & =0 \cdot 0916 \cdot \mathrm{Hs}_{99} \\
\mathrm{MVV}_{\mathrm{C}} & =0.0635 \cdot \mathrm{Hs}_{99} \\
\mathrm{MVV}_{\mathrm{D}} & =0.0488 \cdot \mathrm{Hs}_{99}
\end{aligned}
$$

These relationships essentially predict the MVV of the different parts of the beach profile in terms of different wave conditions
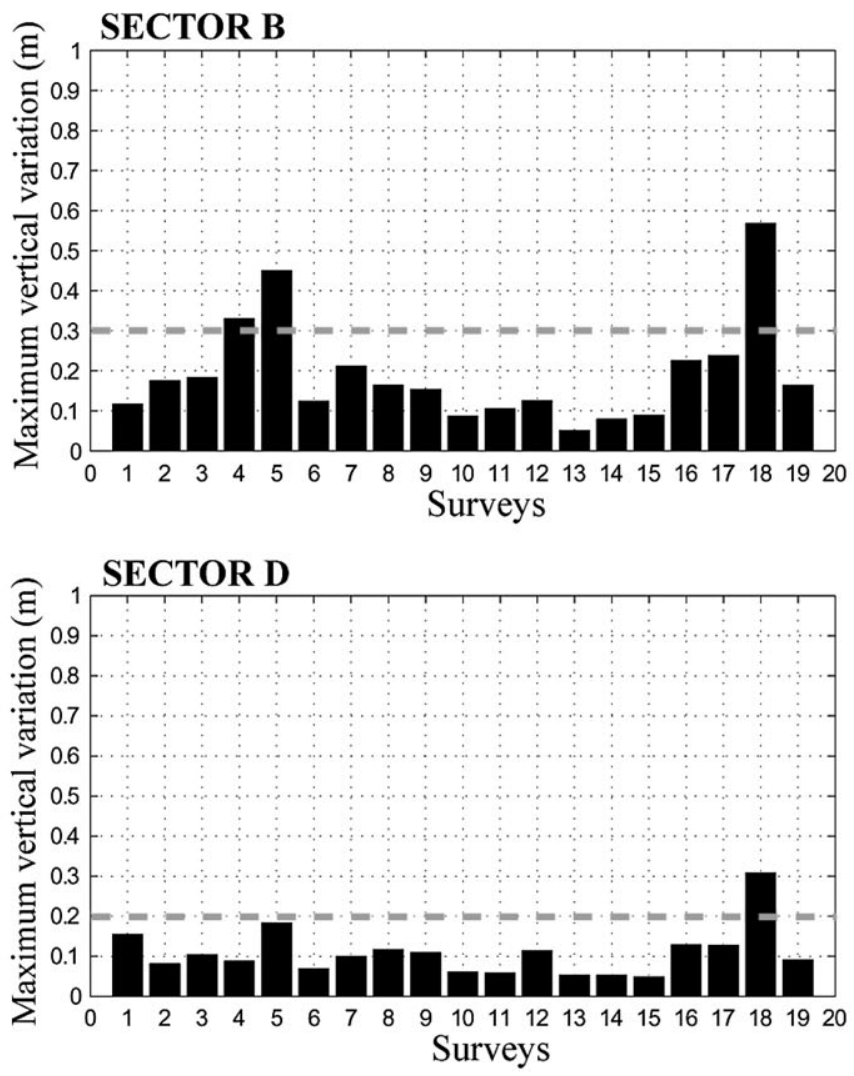

Figure 6. Maximum vertical variation (MVV) between consecutive surveys for all sectors and defined threshold limits. 


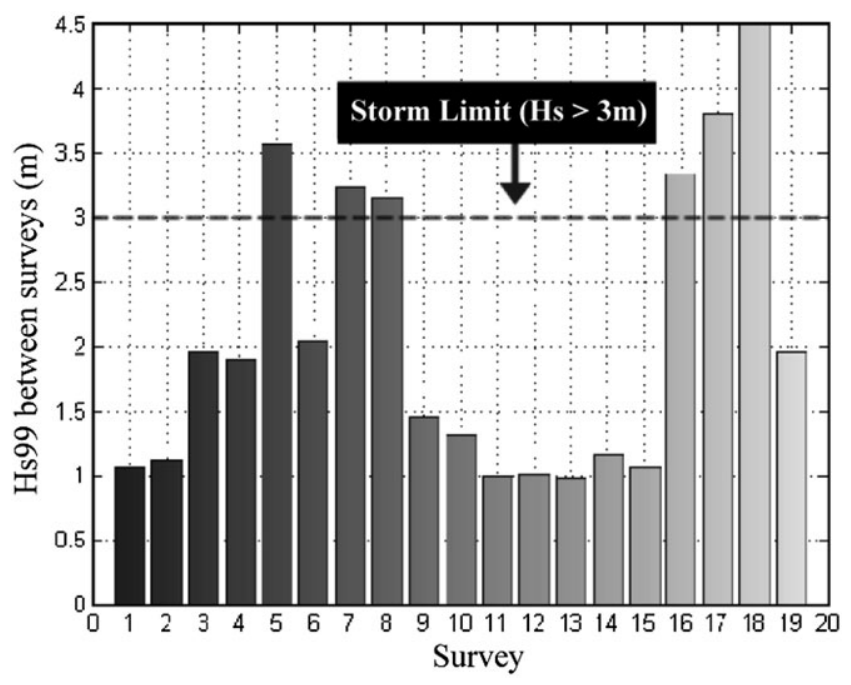

Figure 7. 99th percentile of significant wave height $\left(\mathrm{Hs}_{99}\right)$ between surveys.
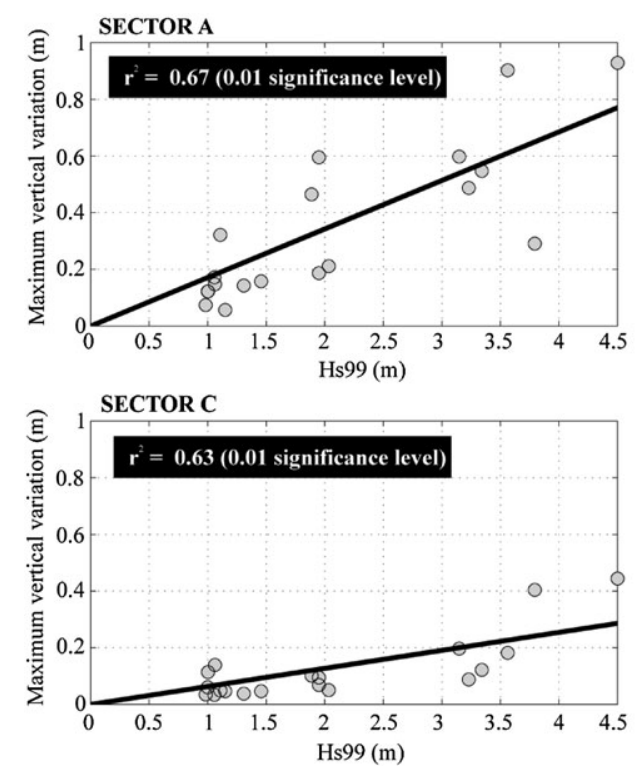

(Figure 9). Using these relationships and the important vertical variations in each sector (sector $A, 0.4 \mathrm{~m}$; sector $B, 0.3 \mathrm{~m}$; sectors $C$ and $D, 0 \cdot 2 \mathrm{~m}$ ), we determined a threshold representing the lower limit of offshore wave height conditions able to generate important morphological changes. For sector $\mathrm{A}$ the threshold $\mathrm{Hs}$ is about $2.3 \mathrm{~m}$; for sectors $\mathrm{B}$ and $\mathrm{C}$ it is approximately $3.2 \mathrm{~m}$; and for sector $\mathrm{D}$ it is about $4.1 \mathrm{~m}$. Therefore, $\mathrm{H}_{99}$ seems to be a good indicator of significant morphological changes on the beach profile even when the period between consecutive surveys is long. Computation of the vertical differences between surveys with $\mathrm{Hs}_{99}>3 \mathrm{~m}$ shows that the footprint left by the storm remains evident through time (Figure 10).

\section{Discussion}

In this study, as a first step towards the definition of thresholds for morphological change on beach profiles, cross-shore sectors were defined based on the standard deviation of elevation change between consecutive surveys. Sectors A (between 20 and $80 \mathrm{~m}$ from profile origin and about 5 to $-1.3 \mathrm{~m}, \mathrm{~m} . \mathrm{s} . \mathrm{I}$.) and $\mathrm{B}$ (between 80 and $170 \mathrm{~m}$ from profile origin and about $-1 \cdot 3$ to $-3 \cdot 4 \mathrm{~m}$ depth, m.s.l.), show the most dramatic vertical changes along the whole profile (Figure 3). These two sectors
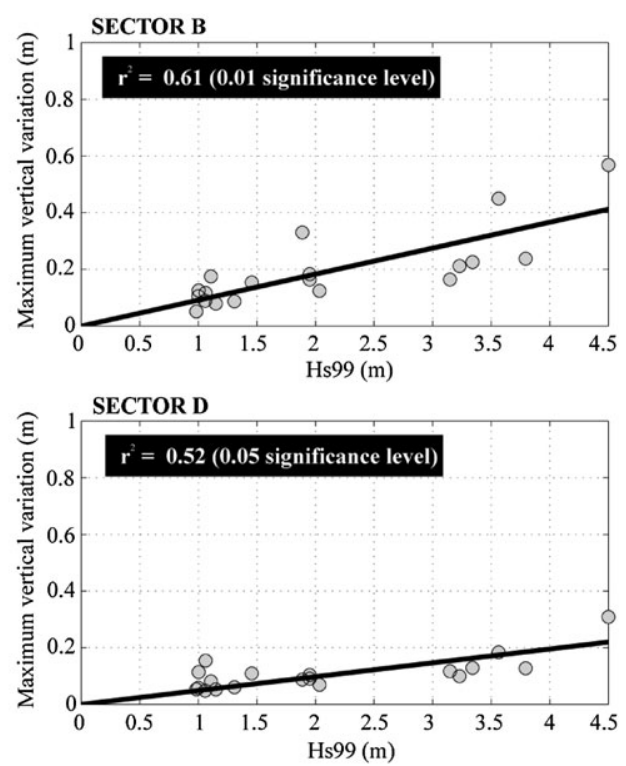

Figure 8. Dispersion diagrams with the maximum vertical variation (MVV) versus $\mathrm{Hs}_{99}$ for sectors $\mathrm{A}-\mathrm{D}$ with a least squares fit. Statistical significance of each correlation is boxed.

Figure 9. Illustration of the maximum vertical variation (MVV) along the four sectors of the profile.

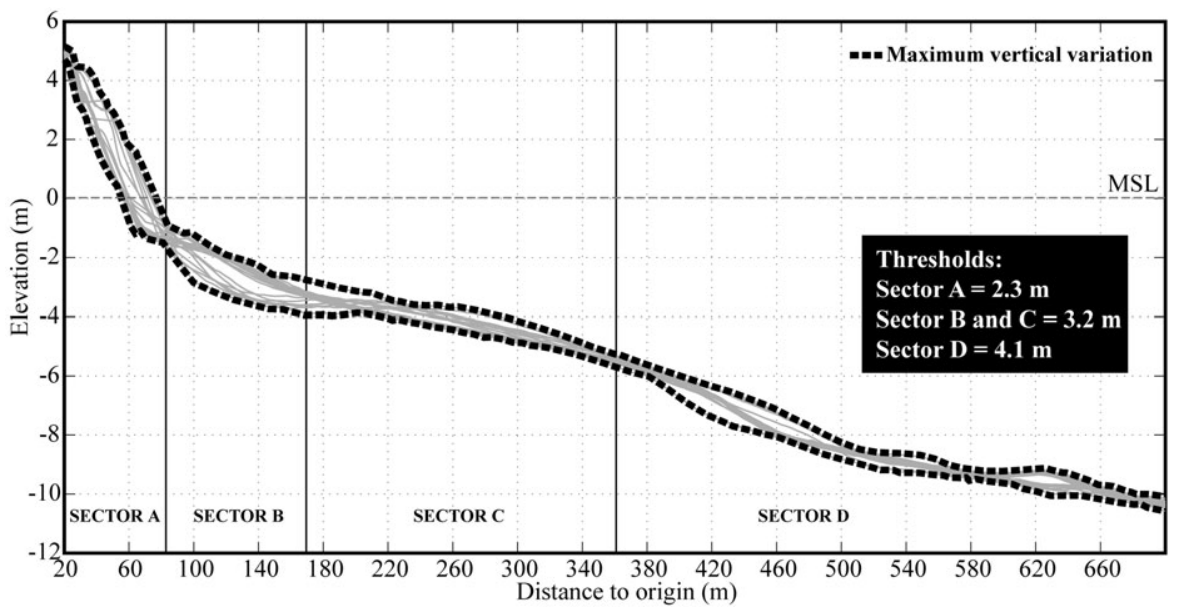

Earth Surf. Process. Landforms (2010) 

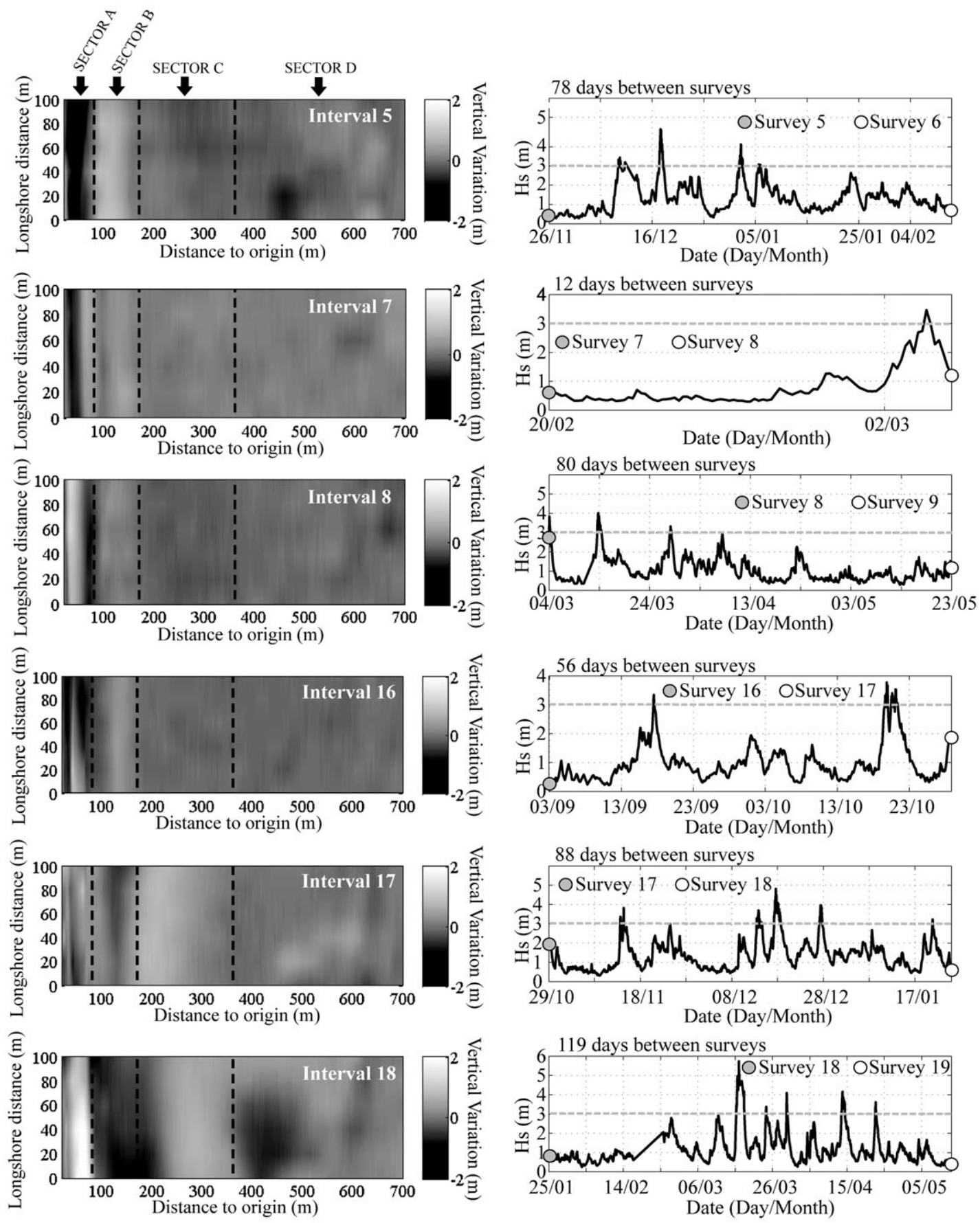

Figure 10. Grid differences between pairs of surveys where $\mathrm{Hs}_{99}$ was above $3 \mathrm{~m}$ (column at left) and $\mathrm{Hs}$ data between the surveys (column at right).

are related to major beach morphological features (Figure 4): the berm (sector A) and the sub-tidal terrace (sector B). The other sector related to a morphological feature is sector $\mathrm{C}$ (between 170 and $360 \mathrm{~m}$ from profile origin and about $-3 \cdot 4$ to $-6 \mathrm{~m}$ depth, m.s.l.), dominated by changes on long-shore bar formation. Sector D (between 360 and $700 \mathrm{~m}$ from profile origin and about -6 to $-10 \cdot 4 \mathrm{~m}$ depth, m.s.I.) does not appear to present a clear relationship with any morphological feature, although the vertical variability in this sector is low, indicating that this part of the profile is less active. The pattern of the standard deviation of height/depth between surveys along the beach profile can be interpreted as differential responses to wave energy by the different sectors, and shows that the inner sectors ( $A$ and $B$ ) undergo a greater magnitude of change than do the offshore sectors. Profile analysis also indicates that the beach system's response to wave conditions is faster for sectors A and B (Figure 8). Similar results were obtained by Reeve et al. (2007) in a study of multi-scale temporal variability of the beach profile at Duck (North Carolina, USA). Volumetric variation observed for individual profiles and the mean variation calculated for the overall profile are similar for the entire monitored period (Figure 5), indicating a relatively uniform along-shore behaviour between the profiles. This helps to consolidate the assumptions made within the study regarding the use of the overall ('mean') profile as reasonably representative of the six profiles measured. Sector B shows a significant negative relationship with sector $A$ for volume variation, especially for the first and second winters (Figure 5), when the volume losses of sector A were transferred to sector B and vice-versa. This represents sediment transfer from the berm to the sub-tidal terrace during high energy conditions (winter storms) and the opposite effect for average energy conditions (storm recovery). During low energy conditions (e.g. second summer, Figure 5), changes are minimal. Sectors $A$ and $C$ yield 
a significant positive correlation, demonstrating that there is no direct sediment transfer between the berm and the long-shore bar, but rather, that sediment transfer from sector B (sub-tidal terrace) occurs to both $\mathrm{A}$ and $\mathrm{C}$.

Computation of MVV, and the definition of threshold vertical variations for each sector, allowed the identification of survey intervals in which important vertical variations occurred (Figure 6). MVV and Hsg9 show the direct relationship between higher MVVs and intervals between surveys during which storm events occurred (Figures 6 and 8). By computing differences between surveys where $\mathrm{Hs}_{99}>3 \mathrm{~m}$ (Figure 10), it was possible to observe that, in some cases, the variations are related to recovery from the storm event (interval 8 and 18), maintaining and preserving the footprint of the storm impact. These findings support the use of both indicators (MVV and $\mathrm{Hs}_{99}$ ), even when the interval between surveys is higher (more than a month). The fit between MVV and $\mathrm{Hs}_{99}$ was computed using values of MVV below the measurement error $(20 \mathrm{~cm})$. Although these values can be considered sampling noise, they represent higher probability of occurrence in a $20 \mathrm{~cm}$ probabilistic interval and therefore the best approach of lower MVV. The sector presenting the best fit between $\mathrm{Hs}_{99}$ and MVV is sector A (the berm), indicating a more rapid morphodynamic response to forcing agents, as found in previous investigations (e.g. Niedoroda et al., 1985; Cowell et al., 1999; Backstrom et al., 2008). With increasing distance from the profile origin, a higher $\mathrm{H}_{99}$ value is required for an important morphological response. Thresholds for significant morphological change in the study area range from $\mathrm{Hs}_{99}=2.3 \mathrm{~m}$ for the berm (sector $\mathrm{A}$ ) to $\mathrm{Hs}_{99}=4 \cdot 1 \mathrm{~m}$ for sector $\mathrm{D}$ (near the depth of closure).

\section{Conclusion}

This study investigated variations in beach profile morphology in the Praia de Faro area (southern Portugal) and their relationship to wave conditions, including significant wave height. Morphological changes in the beach profile were greatest at the beach face/berm and sub-tidal terrace. Sediment lost from the beach face was gained by the sub-tidal terrace, and vice-versa, depending on wave conditions. The relationship between offshore wave height and profile variability allowed three thresholds for morphological change to be defined: waves higher than $2.3 \mathrm{~m}$ are responsible for important morphological changes to the berm and beach face (sector A); waves higher than $3.2 \mathrm{~m}$ are responsible for important changes to the sub-tidal terrace and long-shore bar (sectors B and C, respectively); and waves over $4.1 \mathrm{~m}$ in height are needed to effect morphological change further seaward, near the depth of beach closure (sector D). A wave threshold for predicting morphological changes to the beach profile is of interest and importance to both scientists and coastal planners/managers. The quantitative relationship established between wave conditions and elevation changes could be useful from a coastal management perspective; for example, to predict the impact of storms on the beach or to inform beach nourishment programmes. The method adopted in this study could be applied to any coastal area where cross-shore profiles and off-shore wave data are available for a given monitoring period of not less than one year and encompassing storm/recovery cycles. The study has shown that the division of the beach profile into different sectors according to distinctions in the magnitude of morphological change is a useful tool for investigating cross-shore elements and beach dynamics. The technique may have more limited application to beaches where morphological changes associated with the long-shore component superimpose crossshore behaviour.

Acknowledgements-This research project received funding from the European Community's Seventh Framework Programme under grant agreement No. 202798 (MICORE Project). Field data were obtained during the CROP (CrossShore Processes on Contrasting Environments) project, under contract PDCTM/MAR/15265/99. Particular thanks are due to the Instituto Hidrográfico, who supplied wave and tidal data. The authors would like to thank Simon Connor for English revisions.

\section{References}

Andrade C. 1990. O ambiente de barreira da Ria Formosa, AlgarvePortugal, PhD Thesis, Universidade de Lisboa (unpublished).

Backstrom JT, Jackson DWT, Cooper JAG, Malvárez GC. 2008. Stormdriven shoreface morphodynamics on a low-wave energy delta: the role of nearshore topography and shoreline orientation. Journal of Coastal Research 24(6): 1379-1387.

Balsillie J. 1986. Beach and coast erosion due to extreme event impact. Shore and Beach 54(4): 22-37.

Balsillie J. 1997. Volumetric Beach and Coast Erosion due to Storm and Hurricane Impact, Open File Report. Florida Geological Survey: Tallahassee, FL; 22 pp.

Bettencourt P. 1994. Les environments sedimentaires de la côte sotavento (Algarve, Sud Portugal) et leurs évolution holocène et actuelle, PhD Thesis, Université de Bourdeaux (unpublished).

Birkemeier WA. 1979. The effects of the 19 December 1977 coastal storm on beaches in North Carolina and New Jersey. Shore and Beach 47: 7-15.

Birkemeier WA. 1985. Field data on seaward limit of profile change. Journal of Waterway, Port, Coastal and Ocean Engineering 111(3): 598-602.

Birkemeier WA, Nicholls RJ, Lee GH. 1999. Storms, storm groups and nearshore morphologic change. Proceedings of the Coastal Sediments' 99 Conference. American Society of Civil Engineers (ASCE): Reston, VA; 1109-1122.

Callaghan DP, Ranasinghe R, Short A. 2009. Quantifying the storm erosion hazard for coastal planning. Coastal Engineering 56: 90-93.

Ciavola RT, Ferreira Ó, Dias JA. 1997. Field observations of sandmixing depths on steep beaches. Marine Geology 141: 147-156.

Correia F, Ferreira Ó, Dias JMA. 1997. Contributo das arribas para o balanço sedimentar do sector costeiro Quateira - Vale do Lobo (Algarve - Portugal). Seminário sobre a zona costeira do Algarve: Faro; 31-39 (in Portuguese and unpublished).

Costa M, Silva R, Vitorino J. 2001. Contribuição para o estudo do clima deagitação marítima na costa Portuguesa. 2as Jornadas Portuguesas de Engenharia Costeira e Portuária in CD-ROM (in Portuguese).

Cox JC, Pirrello MA. 2001. Applying joint probabilities and cumulative effects to estimate storm-induced erosion and shoreline recession. Shore and Beach 69(2): 5-7.

Cowell PJ, Hanslow DJ, Meleo J. 1999. The shoreface. In Handbook of Beach and Shoreface Morphodynamics, Short AD (ed.). Wiley: Chichester; 39-71.

De Vriend HJ. 1991. Mathematical modelling and large-scale coastal behaviour; part 1, physical process. Journal of Hydraulic Research 29(6): 727-740.

Direcção Geral de Portos, Navios e Transportes Marítimos (DGPNTM). 1998. Impacte da construção do novo Porto de Pesca no trânsito aluvionar e na configuração das praias, Estudos Complementares, Relatório Final. DGPNTM: Porto (in Portuguese).

Dolan R, Hayden B. 1981. Storms and shoreline configuration. Journal of Sedimentary Petrology 51(3): 737-744.

Dolan R, Davies RE. 1994. Coastal storm hazards. Journal of Coastal Research 12: 103-114.

Dolbeth M, Ferreira Ó, Teixeira H, Marques JC, Dias JA, Pardal MA. 2007. Beach morphodynamics impact on a macrobenthic community along a subtidal depth gradient. Marine Ecology Progress Series 352: 113-124 
Fenster MS, Dolan R, Morton RA. 2001. Coastal storms and shoreline change: signal or noise. Journal of Coastal Research 17: 714-720.

Ferreira Ó. 2005. Storm groups versus extreme single storms: predicted erosion and management consequences. Journal of Coastal Research 42: 221-227.

Ferreira O. 2006. The role of storm groups in the erosion of sandy coasts. Earth Surface Processes and Landforms 31(8): 1058-1060.

Ferreira Ó, Dias JA, Gama C, Taborda R. 1995. Quantification of beach erosion caused by storms on the Portuguese coast. In Directions in European Coastal Management, Healy MG, Doody JP. Samara Publishing: Key Biscayne, FL; 267-273.

Ferreira Ó, Martins JT, Dias JA. 1997. Morfodinâmica e vulnerabilidade da Praia de Faro. In Seminário sobre a Zona Costeira. EUROCOAST: Porto; 67-76 (in Portuguese).

Komar PD. 1976. Beach Processes and Sedimentation. Prentice-Hall: Upper Saddle River, NJ; 429 pp.

Hallermeier R. 1981. Seaward limit of significant sand transport by waves: an annual zonation for seasonal profiles. Coastal Engineering Technical Aid 81-82: 23.

Honeycutt MG, Crowell MC, Douglas BC. 2001. Shoreline-position forecasting: impact of storms, rate-calculation methodologies, and temporal scales. Journal of Coastal Research 17(3): 721-730.

Inman DL, Dolan R. 1989. The outer banks of North Carolina: budget of sediment and inlet dynamics along a migrating barrier system. Journal of Coastal Research 5: 193-237.

Larson M, Kraus NC. 1995. Prediction of cross-shore sediment transport at different spatial and temporal scales. Marine Geology 117: 75-94.

Lee G, Nicholls RJ, Birkemeier WA. 1998. Storm-induced profile variability of the beach-nearshore profile at Duck, North Carolina, USA, 1981-1991. Marine Geology 148: 163-177.

Lozano I, Devoy RJN, May W, Andersen U. 2004. Storminess and vulnerability along the Atlantic coastlines of Europe: analysis of storm records and greenhouse gases induced climate scenario. Marine Geology 210: 205-225.

Martins JT, Ferreira Ó, Dias JA. 1997. A susceptibilidade da Praia de Faro à erosão por tempestades. Comunicações do $9^{\circ}$ Congresso do Algarve, Racal Clube: Silves; 206-213 (in Portuguese).

Morton RA. 2002. Factors controlling storm impacts on coastal barriers and beaches a preliminary basis for real-time forecasting. Journal of Coastal Research 18(4): 838-838.
Morton RA, Gibeaut JC, Paine JG. 1995 Meso-scale transfer of sand during and after storms: implications for prediction of shoreline movement. Marine Geology 126(1-4): 161-179.

Niedoroda AW, Swift DJP, Hopkins TS. 1985. The shoreface. In Coastal Sedimentary Environment, Davis RA Jr (ed.). Springer: New York; 533-624.

Pessanha LE, Pires HO. 1981. Elementos sobre o clima de agitação marítima na costa sul do Algarve. Instituto de Meteorologia e Geofísica: Lisbon (in Portuguese).

Pires HO. 1998. Preliminary Report on the Wave Climate at Faro, Project India. Instituto de Meteorologia - Instituto Superior Técnico: Lisbon; 37 pp. (not published).

Reeve D, Li Y, Lark M, Simmonds D. 2007. An investigation of the multi-scale temporal variability of beach profiles at Duck using wavelet packet transforms. Coastal Engineering 54: 401-415.

Sá-Pires C, Morris B, Ferreira Ó, Matias A, Vila-Concejo A, Dias JA. 2002. Monitoring program to determine cross-shore changes in beach morphology. Contribuição para a dinâmica geomorfológica. Publicações da Associação Portuguesa de Geomorfólogos 1: 127134 (in Portuguese).

Short AD. 1999. Handbook of Beach and Shoreface Morphodynamics, Short AD (ed.). Wiley: Chichester; 134 pp.

Steetzel HJ. 1993. Cross-shore transport during storm surges. Delft Hydraulics Communication 476 pp.

van Rijn LC. 2009. Prediction of dune erosion due to storms. Coastal Engineering 56: 441-457.

Vila-Concejo A, Matias A, Pacheco A, Ferreira Ó. 2006. Quantification of inlet-related hazards in barrier island systems. An example from the Ria Formosa (Portugal). Continental Shelf Research 26: 10451060.

Winant CD, Inman DL, Nordstorm CE. 1975. Description of seasonal beach changes using empirical eigenfunctions. Journal of Geophysical Research 80(15): 1979-1986.

Woodroffe CD. 2002. Coasts: Form, Process and Evolution. Cambridge University Press: Cambridge; 444 pp.

Wright LD, Short AD. 1984. Morphodynamic variability of surf zones and beaches: a synthesis. Marine Geology 56: 93-118.

Zhang K, Douglas BC, Leatherman SP. 2001. Beach erosion potential for severe Nor'easters. Journal of Coastal Research 17: 309-321. 